\title{
PENILAIAN FORMATIF PESERTA DIDIK ATAS KOMPETENSI PENDIDIK DALAM PROSES PEMBELAJARAN
}

\author{
Jusuf Blegur \\ jusufblegur@ukaw.ac.id \\ FKIP- \\ Universitas Kristen Artha Wacana \\ M. Rambu P. Wasak \\ rambuwasak@ukaw.ac.id \\ FKIP- \\ Universitas Kristen Artha Wacana \\ Lukas Manu \\ lukasmanu@ukaw.ac.id \\ FKIP- \\ Universitas Kristen Artha Wacana
}

\begin{abstract}
This study aims to assess teachers' competence in learning process. Research used is quantitative approach designed descriptively. The research paticipant are 76 studens determined by proportional stratified random sampling technique (class A to $F)$. The data for teaching competency were collected using questionnaire developed by the Ministry of Education and Culture (2015), involving 28 closed-statements with Likert scale model. The questionnaire was responded on a scale of 5 to 1 (very good/very high/always up to not good/very low/never). All data is processed by descriptive analysis using SPSS 20.00 for windows. The result is that the 9 courses which are assessed formatively by the participants indicated that the teaching competence is in the very high category (69\%) so that it needs to be maintained and developed continuously.
\end{abstract}

Keywords: Formative assessment, teacher's competence.

\section{PENDAHULUAN}

Gejolak zaman yang kian laju dan kompleks harus dapat ditimpali dengan lajunya kualitas pembelajaran. Pembelajaran tidak hanya dilihat sebagai rutinitas, namun dampak-dampak apa yang dirasakan peserta didik saat menjalani proses pembelajaran, baik berjangka pendek, menengah maupun panjang. Agar keberdampakan menjadi maksimal, pembelajaran haruslah ditangani oleh pendidik-pendidik yang kompeten (Asmarani, 2014; Hakim, 2015; Manu \& Manu, 2017). Pendidik yang dengan berbagai set keterampilan dapat meningkatkan efisiensi untuk pembelajaran yang berkualitas. Selalu mengutamakan inovasi, tidak terkungkung dalam pengalaman belajar konvensional. Mencuplik pengalaman belajar sebelumnya dan sekarang untuk mengembangkan pembelajaran yang visioner, beriringan dengan kebutuhan zaman yang ditekankan Ummah, Aunillah, \& Kurniawan (2013) hanya dapat dilakukan oleh pendidik yang bertaraf atau kompetensinya dapat terukur secara baik.

Kompetensi merupakan kemampuan, kecakapan, keterampilan, dan pengetahuan 
seseorang di bidang tertentu. Jadi kata kompetensi ditakrifkan sebagai kecakapan untuk melakukan suatu tugas atau suatu keterampilan dan kecakapan yang dilimitasikan atau terstandarisasi pemerintah, baik berupa kegiatan, perilaku, maupun hasil yang ditampilkan dalam proses pembelajaran (Musfah, 2011; Ismail, 2010; Suyanto \& Djihad, 2012). Kompetensi juga mengarah kepada totalitas pendidik untuk beradaptasi dalam lingkungan kerja, menjalankan tugas dengan kemampuan terbaiknya (Musfah, 2011) dan sesuai asas dan etika yang berlaku dan ditetapkan sebagai standar nasional dalam proses dan pengembangannya secara universal. Keterampilan dan kecakapan yang ajeg menjadi preskriptif yang harus disanggupi pendidik saat menjalankan tugasnya (sambil pengembangan). Pendidik berperan laksana fasilitator, mediator, konselor, eksplanator, konfirmator, motivator, inspirator, dan inovator selama kegiatan pembelajaran serta benar-benar mengoptimalisasi peserta didik atas talenta yang dimiliki.

Pendidik yang kompeten sebagai tonggak utama mereformasi proses pembelajaran yang berkualitas dan bermakna seperti dari teachercentered ke student-centered. Untuk itu, pendidik harus insaf bahwa manusia adalah sosok yang peka terhadap perubahan dan perkembangan serta membuka diri agar terus berkembang menjadi individu yang kompeten dalam profesinya (Suyanto \& Djihad, 2012). Menginvestasikan pendidik yang kompeten dalam proses pembelajaran sangatlah esensial, pendidik yang kompeten dapat mengiringi peserta didik pada proses pembelajaran ideal, yang menekankan pengembangan potensi yang dimiliki peserta didik dalam skema holisitik (kognitif, afektif, maupun psikomotor), seperti dalam mandat undang-undang. Inisiatifnya tinggi untuk proaktif mengembangkan kompetensinya secara periodik guna menopang capaian kompetensi lulusan pada satuan pendidikan (Indrawati, 2006; Kurniawan, Faisal, Murniati, Nyoman, \& Khoiri, 2011).

Kinerja yang baik dan progresif selalu ditampilkan oleh pendidik-pendidik yang berkompeten (Wahyudi, 2010; Barinto, 2012; Saragih, 2013). Pendidik harus berwatak hangat dan ramah, sosialis dan humanis, memiliki visi yang jelas serta berkomitmen untuk belajar sepanjang hayat, mengeksekusi dengan cermat apa pun yang direncanakan. Urusan manajemen dilakukan secara efektif, baik di dalam dalam di luar kelas. Keahliannya saat presentasi materi pelajaran dapat mencuri perhatian peserta didik. Ia mampu memotivasi peserta didik (Bhargava \& Pathy, 2011; Suyanto \& Djihad, 2012) sehingga tidak adanya kepasakan, kepekatan, kelelahan, dan kemalasan berarti selama kegiatan pembelajaran. Pendidik yang efektif di kelas akan menjamin kompetensi dirinya dan positifnya hasil belajar (Brundrett \& Silcock, 2002; Nadeem, Rana, Lone, Maqbool, Naz, \& Ali, 2011; Hamilton-Ekeke, 2013; Ahmad \& Jinggan, 2015).

Pendidik wajiblah merias atau melengkapi diri dengan beragam ilmu pengetahuan dan teknologi terkini yang dikontekstualisasikan secara tepat sehingga kompetensinya memenuhi standar kualitas dari waktu ke waktu. Kompetensi pendidik haruslah dinilai dan dievaluasi secara berkala atau disebut Palupi \& Sulton (2017) sebagai penilaian proses (formative assessment). Inilah ikhtiar membentuk pembelajaran yang berkualitas seturut desakan zaman. Bermodal kualifikasi akademik untuk melegitimasi seorang pendidik berkompetensi tidaklah cukup (bukan jaminan utama), sebab kompetensi itu komprehensif. Singkatnya, pendidik yang 
berkompeten adalah mereka yang mampu mengefektifkan dan mengefisiensikan pendekatan, metode, dan strategi pembelajaran dengan kepakaran, kepribadian, serta relasi sosialnya guna mengeksplorasi potensi peserta didik secara maksimal selama proses pembelajaran sebagai upaya mempersiapkan peserta didik "hidup dan berguna" di zaman mendatang. Dengan melakukan penilaian secara berkala terhadap kompetensi, pendidik akan terbantu untuk mengetahui kelalaiankelalaiannya yang selanjutnya diperbaiki guna menyajikan pembelajaran yang berkualitas bagi peserta didik.

\section{METODE PENELITIAN}

Partisipan adalah mahasiswa semester IV program studi Pendidikan Jasmani, Kesehatan, dan Rekreasi, Universitas Kristen Artha Wacana, Kupang, Indonesia yang berjumlah 76 orang (57 pria dan 19 wanita) yang ditetapkan menggunakan teknik proporsional stratified random sampling (kelas $\mathrm{A}=11, \mathrm{~B}=11, \mathrm{C}=11, \mathrm{D}=13, \mathrm{E}=16$, dan $\mathrm{F}$ = 14). Partisipan kelompokkan menjadi 3 bagian agar memudahkan pemetaan pendidik serta kompetensinya, kelas dimaksud termasuk kelas tipe kelas 1 yakni kelas $\mathrm{AB}$, tipe kelas 2 yakni CD, dan tipe kelas 3 yakni EF. Penentuan sampel ini ditarik dari jumlah populasi sebanyak 180 mahasiswa.

Data dikumpul dengan kuesioner yang diadopsi dari Kementerian Pendidikan dan
Kebudayaan Republik Indonesia (2015) secara khusus mengukur kompetensi pendidik yang juga dipakai dalam proses seleksi sertifikasi dosen dengan melibatkan 28 pernyataan tertutup, yang meliputi: 1) Kompetensi pedagogik, nomor 1-9, 2) Kompetensi profesional, nomor 10-17; 3) Kompetensi kepribadian, nomor 18-23, dan 4) Kompetensi sosial, nomor 24-28. Kuesioner didesain dengan model skala Likert dengan respon partisipan pada skala 5 s.d 1 (sangat baik/sangat tinggi/selalu sampai dengan sangat tidak baik/sangat rendah/tidak pernah).

Proses analisis yang digunakan adalah analisis deskriptif kuntitatif. Analisis ini membantu peneliti dalam pengelompokkan kompetensi pendidik pada empat dimensinya, yaitu pedagogi sampai dengan sosial. Dengan data frekuensi dan persentase, dicandrakan angka-angka dari instrumen penelitian yang selanjutnya digunakan sebagai dasar untuk menilai kompetensi pendidik (sangat rendah sampai sangat tinggi).

\section{HASIL DAN PEMBAHASAN}

Kompetensi mengajar untuk pendidik telah dirampung dari 3 "tipe kelas". Sehingga akan disajikan berdasarkan jumlah mata kuliah (9 mata kuliah) pada 5 titik skala, yakni sangat rendah sampai dengan sangat tinggi seperti pada gambar 1 . 


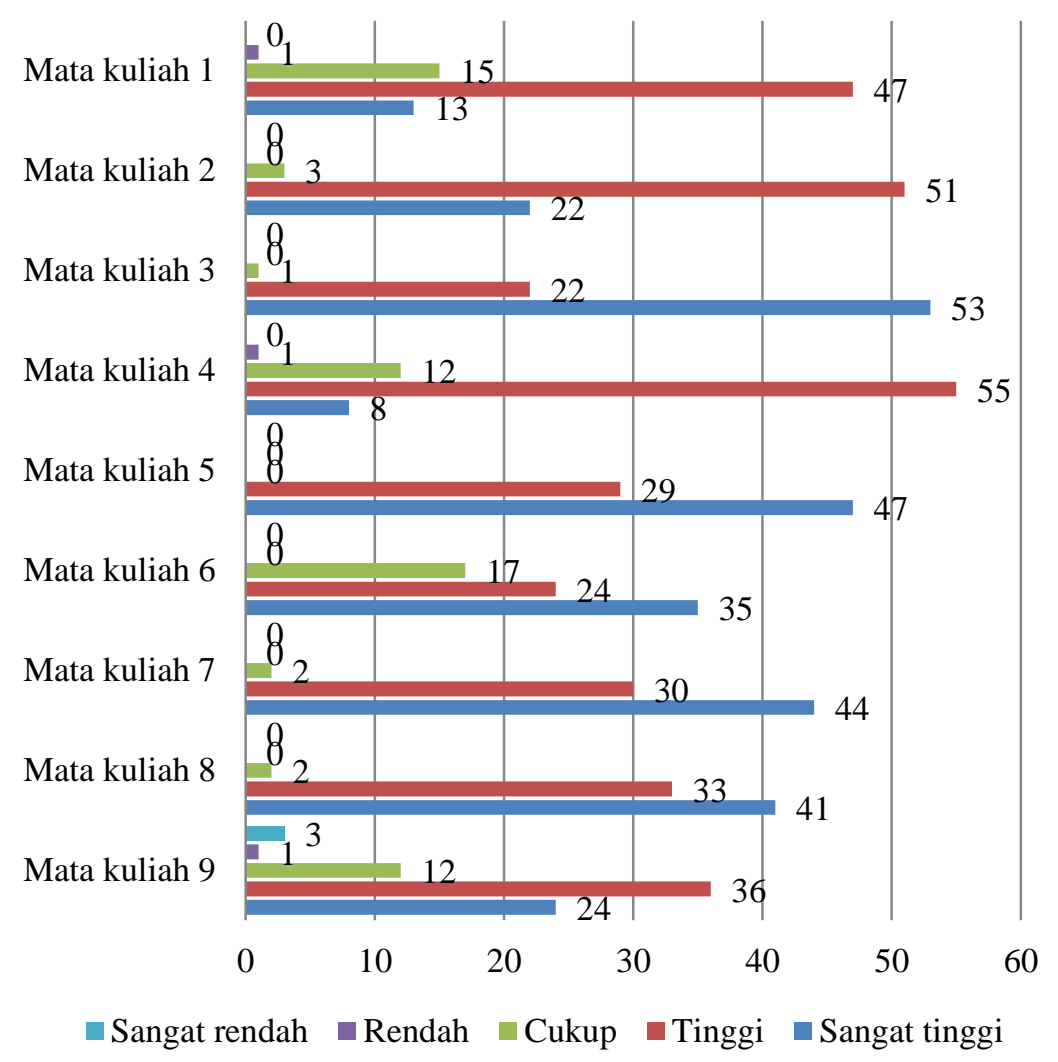

Gambar 1.Kompetensi pendidik per mata kuliah

Setelah membahas kompetensi gambar 2) yang menjelaskan bahwa 5 pendidik per mata kuliah dan per kelas, (69.0\%) partisipan memberi tanggapan maka tahap ini telah disederhanakannya kompetensi mengajar pendidik yang sangat kompetensi pendidik yang mengajar. tinggi.

Seperti terlihat dalam piechart (lihat

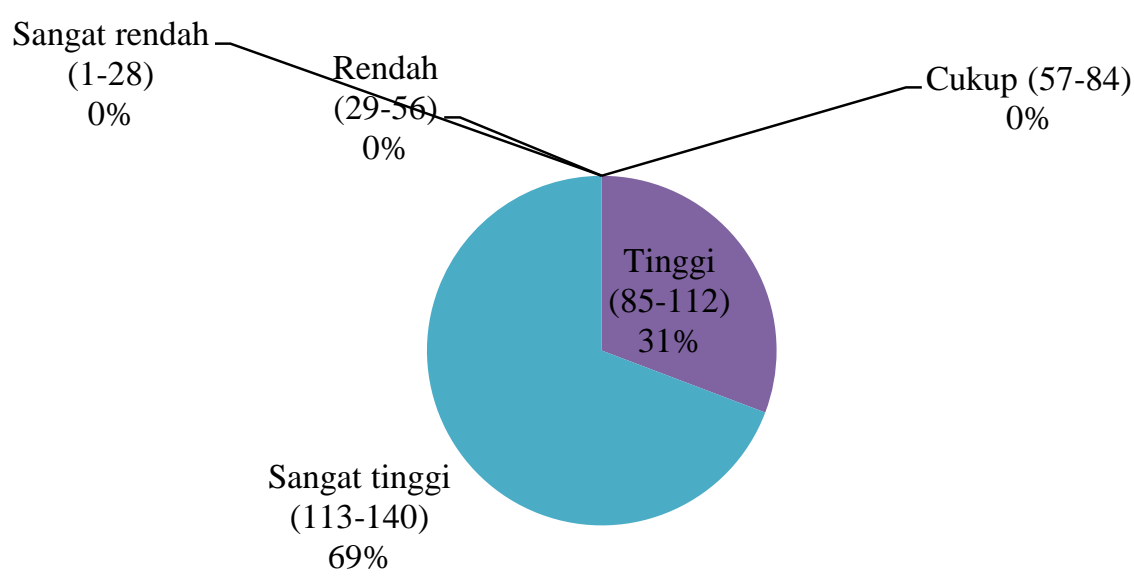

Gambar 2.Rangkuman kompetensi pendidik

Kompetensi yang terlihat dalam sosial. Untuk itu, pembahasan hasil penelitian piechat di atas sebagai penilaian akhir dari lebih difokuskan kepada empat dimensi kompetensi pendidik, baik dari aspek kompetensi sebagaimana yang tercantum pedagogik, profesional, kepribadian, maupun dalam kuesioner penelitian dari pernyataan 
nomor 1 sampai dengan pernyataan nomor 28 . Indikator-indikator yang dibahas dari setiap aspek kompetensi ialah indikator yang dalam proses penilaian formatif masih perlu mendapat perhatian dari pendidik.

\section{Kompetensi Pedagogik}

Kompetensi ini mempelajari dan mempertanyakan pengetahuan, kemampuan/ keterampilan, dan kinerja pendidik dalam mengelola proses pembelajaran (Syahruddin, Ernawati, Ede, Rahman, Sihes, \& Daud, 2013). Ilmu-ilmu yang berlandas pada kependidikan harus dimiliki oleh pendidik sehingga dalam memilih pendekatanpendekatan pembelajaran tetap berbasis pada perihal kemunusiaan yang unik dan universal agar otorisasi pendidik pada "kehendakkehendak" tertentu dapat dihindari. Konsepsi kependidikan yang baik membantu pendidik agar mengenali secara utuh setiap peserta didiknya. Menjadikannya tidak arogan saat membuat pemerataan terhadap kelebihan dan keterbatasan peserta didiknya. Pemahaman yang baik atas kemampuan peserta didik, mengantarkan pada pembelajaran yang diselaraskan dengan karakterisasi pembelajar. Seperti capaian tertinggi seorang peserta didik dapat berbeda satu sama lainnya, yang lainnaya bisa superior dan disaat yang sama ada juga yang masih terbatas. Namun untuk ukurannya (peserta didik dimaksud), itu bisa saja adalah kemampuan terbaiknya.

Kompetensi pedagogik yang baik juga ditandai dengan peran aktifnya pendidik dalam mengembangkan proses pembelajaran yang seturut dengan kebutuhan era. Ia perlu mengumpulkan data-data yang bertalian dengan pengembangan konsep belajar kekinian. Menurut Musfah (2011), pendidik harus dapat membekali peserta didik dengan ilmu pengetahuan, keterampilan, dan sikap untuk menghadapi masa depan. Peran pendidik hanya memfasilitasi semua aktifitas belajar. Diawali dengan menyusun kegiatan belajar sesuai tuntutan kurikulum (C4, C5, dan C6), seperti bagian taksonomi yang wajibnya digarap oleh peserta didik (pendidikan tinggi) agar peserta didik memiliki kemampuan penalaran dan pengembangan atas berbagai konsep dan praktik sebagai upaya pengembangan diri. Artinya, rancangan pendidik sudah seharusnya memperhatikan level pendidikan peserta didik dengan terus melakukan evaluasi secara berkala sehingga peserta didik dapat mengaktualisasikan dirinya secara maksimal.

Kompetensi pedagogik pendidik dalam penelitian ini terlihat baik, namun untuk kepentingan pengembangan ada hal-hal yang membutuhkan perhatian serius dari pendidik. Melihat waktu belajar yang ada di siang hari, padat, dan berturut-turut pendidik perlu menyelipkan ragam strategi dalam menghidupkan suasana kelas, cerita atau bahwa kalimat-kalimat joke dapat dipakai guna meleburkan atau merefreskan kembali perasaaan peserta didik. Suasana kelas juga dapat disiasati dengan lebih dinamis, biarkan peserta didik berdiskusi bebas sesuai bidang garapan mereka, tanpa harus terlihat duduk, diam, dan sopan namun tidak kritis dan kreatif. Pada sisi lainnnya, hargailah usaha atau prestasi yang peserta didik ukir di luar kelas. Seperti mengikuti lomba debat, wasit bola voli, pemain sepakbola peserta konferensi, melakukan publikasi ilmiah, dan sebagainya. Agar memberi kesadaran kepada mereka bahwa belajar tidak terbatasi oleh "dinding", melainkan menjemput peluang pengembangan diri secara berkelanjutan. Inilah produk nyata dari apa yang peserta didik pelajari, sehingga jangan membatasi ruang inisiatif peserta didik yang agresif dan brilian. 
Sampai saat ini, keterlibatan teknologi dalam proses pembelajaran masih sangat minim. Untuk beberapa MK mereka iniasiasikan secara mandiri dengan membeli infokus. Namun bagi yang belum ada, peserta didik menjustifikasi dengan meleknya pemanfaatan teknologi informasi. Di era ini, sebaiknya kebutuhan belajar seperti infokus dan internet sudah dapat dipakai secara mandiri dan lancar guna mengembangkan proses pembelajaran yang kritis dan analitis. Tugas-tugas yang diberikan kepada peserta didik juga harus diikuti pengembangan dan tindak lanjutnya, bukan sekedar aktivitas formalitas. Pendidik mengidentifikasi setiap tugas lalu memberikan solusi terkait kendala yang perlu diperbaiki peserta didik. Umpan balik ini juga direkomendasikan agar bermuara pada permasalahan yang dikaji, jangan pada subjeknya. Jika tidak, peserta didik menjadi canggung untuk tampil. Keterampilan persentasi pun wajib diberi umpan balik, sehingga peserta didik mempersiapkan diri sebagai pribadi dengan seperangkat pengetahuan dan keterampilan yang memadai.

\section{Kompetensi Profesional}

Pendidik yang profesional bertanggungjawab terhadap profesi yang diembannya. Mengerahkan segala kemampuan terbaik untuk memberi pelayanan dalam proses pendidikan dan pembelajaran. Ia selalu memvisikan agar peserta didik yang diajari dan dampinginya harus lebih baik dan berguna dari dirinya (pendidik) kelak, dengan membhaktikan kemampuan terbaiknya. Ia juga bertanggung jawab atas setiap keberhasilan peserta didik (Rubio, 2009; Asmarani, 2014) untuk itulah penguasaan terhadap pengembangan ilmu pengetahuan yang mutakhir dalam bidang kelimuan dan pengembangan media pembelajaran adalah bagian dari upaya pengembangan kompetensi profesional. Ia mencari solusi atas setiap masalah-masalah yang dijumpainya dengan membaca kajiankajian terkini melalui buku, prosiding, dan jurnal yang diedarkan secara lokal, nasional, regional, maupun internasional.

Mencermati tuntutan di atas, maka profesionalitas juga mencakup penguasaan bahasa-bahasa internasional. Upaya ini akan membantu pendidik dalam mengembangkan jaringan kerjasama lintas disiplin ilmu maupun lintas institusi dan lintas negara. Ini kian nyata apabila komunikasi internasional kita dapat terbangun secara baik dan berkelanjutan. Tidak hanya dengan membaca, namun pendidik juga perlu menghasilkan produk nyata (karya akademiknya), untuk memberi jaminan kepada peserta didik dan khalayak atas kompetensi profesional yang dimilikinya. Dengan demikian, legalitas ilmuan yang profesional tidak terbatas pada gelar akademik semata, namun pendidik berkontribusi secara nyata dalam mimbar-mimbar akademik bertaraf nasional maupun internasional. Upaya untuk mengembangkan profesionalitas ini pernah direkomendasikan oleh Kurniawan (2016) dengan menggunakan one-one supervision yang berorientasi pada distribusi pengalaman dosen senior, memberikan saransaran perbaikan, serta memonitor secara berkala.

Acuan utama yang selama ini dipakai dalam proses pembelajaran (buku), kiranya dikembangkan lagi atau mendapatkan pengayaan dari dukungan prosiding dan jurnal. Hasil-hasil penelitian dijadikan sebagai bahan diskusi yang elok untuk melatih kekritisan berpikir yang bersandar pada kajian ilmiah. Pendidik sedikit ekstra dengan menyediakan buku, prosiding, dan jurnal untuk kepentingan belajar peserta didik. Apalagi sumber-sumber belajar dimaksud ada juga nama pendidik- 
pendidik yang mengampuh peserta didik pada saat itu. Kredibilitas kompetensi pendidik kian tinggi dimata peserta didik. Selain itu, latihlah peserta didik secara baik untuk mendapatkan prosiding dan jurnal pada lembaga publikasi online. Ketergantungan kepada pendidik dalam mendapatkan informasi dapat diatasi dan peserta didik kian "liar" dalam mencari dan menggali informasi terkini, sekaligus menjadi dimensi yang mengukur performa dan keterampilan untuk menjadi pendidik dengan perilaku prestatif (Ismail, Al-Zoubi, Rahman, \& Al-Shabatat, 2009).

Libatkan peserta didik saat melakukan penelitian-penelitian, misalnya pada skim penelitian unggulan fakultas, unggulan universitas, maupun skim-skim nasional seperti penelitian dosen pemula dan lainnya. Akan memberi dampak yang positif bagi peserta didik untuk pengalaman belajar yang lebih nyata dan konkrit tentang aktivitasaktivitas akademik. Profesionalitas dalam publikasi ini sangat penting, tidak hanya menguntungkan perseorangan (pendidik dan peserta didik), namun jauh lebih pentingnya ada pada lembaga penyelenggara pendidikan. Ini adalah satu poin kritis yang menunjang akreditasi universitas yang pada saat bersamaan cenderung dilupakan oleh sejumlah dosen dalam menyelenggarakan Tri Dharma Pendidikan Tingginya.

\section{Kompetensi Kepribadian}

Kompetensi kepribadian ini memang terlihat mudah-mudah saja, namun proses aplikasinya cukup rumit. Pendidik melatih dan diri sebagai pribadi yang "mulia" di depan peserta didik, seperti perilaku-perilakunya yang jauh dari kontroversi (horisontal dan vertikal), selalu stabil dan konsisten dalam menerapkan aturan-aturan yang telah digulirkan atau disepakati bersama peserta didik. Pendidik menganjurkan agar peserta didik disiplin, namun apa jadinya jika hal serupa tidak ada dalam diri pendidik. Selain itu, pendidik menganjurkan agar peserta didik tidak boleh merokok, namun pendidik sendiri adalah pecandu atau pemadat rokok. Contoh perilaku buruk inilah yang oleh Blegur, Wasak, Tlonaen, \& Manggoa (2017) dapat melunturkan kewibawaan pendidik di depan peserta didik dan membuat peserta terjebak dalam perilaku indisipliner.

Kepribadian pendidik juga diuji dalam hal pengambilan keputusan yang jujur, adil, dan bijaksana. Pendidik selalu memandang bahwa setiap peserta didik adalah anakanaknya sendiri tanpa tebang pilih dalam memberi perlakuan. Misalnya si Andi mendapat nilai bagus karena sealiran agama dengan pendidik. Lukas lebih dipercayai dalam urusan pembelajaran karena Adik atau Saudara pendidik. Ataupun Mince yang diberi beasiswa sebab cantik bagi pendidik, walaupun Ia mapan secara ekonomi. Membuat keputusan seharusnya berbasis pada keobjektifan dan kebenaran data agar peserta didik menjadi puas dalam menyikapi keterbatasannya, meski Ia gagal dalam MK tertentu, Ia tetap menghargai pendidik sebab keputusan yang diberikan memang beralaskan pada data-data yang objektif.

Satunya kata dan tindakan yang ditampilkan sangat mempengaruhi peserta didik dalam mempersepsikan kepribadian pendidik. Agar tidak terkesan ada perilaku "melawan" dari peserta didik, ada baiknya pendidik menjalankan apa yang Ia sampaikan dan sampaikanlah apa yang dijalankan, bukan sebaliknya. Selama ini tidak terjadi, maka peserta didik tetap berpersepsi miring atas setiap ucapan dan tindakan pendidik dan tentu aura segan terhadap pendidik tidak ada, yang ada hanyalah perasaan takut atas "teror tidak 
lulus" yang kerap dialami peserta didik saat ketidakpuasan pendidik terhadap sikap-sikap analitis dan kritis yang kerap dilontarkan perserta didik kepada pendidik selama berlangsungsunya proses pembelajaran.

Zaman selalu bergerak maju bahkan sangat cepat laju perkembangannya. Untuk itu, pendidik pun harus dapat melakukan penyesuaian-penyesuaian atas kemajuan tersebut. Pembelajaran harus selalu di upgrade agar kelas belajar yang dijalankan tidak monoton dari tahun ke tahun. Ini bukan tentang kemajuan semata, namun lebih kepada tanggung jawab pribadi yang peduli terhadap profesi yang Ia jalani. Memberikan pelayanan secara maksimal di dalam kelas, sehingga peserta didik tersadar bahwa profesi pendidik adalah sesuatu yang mulia sehingga jangan dipandang sepeleh. Siapa tahu diantara puluhan peserta didik, mereka kelak menjadi orang berpengaruh yang mengambil keputusan pengembangan pendidikan. Ini warisan agar marwah pendidik terus terjaga di tengah masyarakat. Kalau kita sendiri tidak mampu menjadi teladan, siapa yang tertarik dengan profesi kita?

\section{Kompetensi Sosial}

Komunikasi yang pendidik gunakan dalam proses pembelajaran tidak boleh searah dan terbatas dalam lingkup pembelajaran. Namun bangunlah keintiman dengan peserta didik, sejawat, tenaga kependidikan, serta orang tua yang telah mempercayakan anak mereka kepada kita, inilah indikator yang dipakai Hakim (2015) untuk mengukur kompetensi sosial pendidik. Bangunlah komunikasi yang efektif agar setiap perkembangan belajar peserta didik dapat terpantau dengan baik. Selama pendidik tidak terbuka dengan peserta didik, ada banyak masalah tidak terungkap dengan baik di hadapan pendidik, sehingga Manu \& Blegur (2017) merekomendasikan agar pendidik juga seharusnya menjadi orang tua bagi peserta didik selama berada di sekolah. Jika tidak, peserta didik lebih memilih berdiam diri sambil terus terkukung dengan masalah yang Ia derita sehingga menghambat aktualisasi dirin peserta didik dalam aktivitas pembelajaran.

Mengenali peserta didik secara baik adalah salah satu ciri dari matang kompetensi sosial yang sepatutnya pendidik bangun. Ia peduli dengan peserta didik atau orang lain, sehingga orang lain dikenalinya secara baik. Minimal nama setiap peserta didik Ia ketahui, sehingga saat melangsungkan aktivitas pembelajaran, untuk kepentingan tertentu pendidik dapat memanggil atau mengucapkan nama peserta didiknya secara tepat, ini memberi kesan yang positif pada diri peserta didik. Minimal Ia merasa bahwa pendidik mempedulikan dirinya atau setidaknya pendidik tahu bahwa Ia adalah bagian dari kelas belajar. Sesekali ajaklah mereka bercanda, agar mereka merasa bahwa pendidik adalah orang tua, kakak, sekaligus mitra bagi mereka dalam merencanakan hal-hal akademiknya.

Pendidik perlu mempertimbangkan toleransi atas peserta didik. Apakah itu soal keterlambatan masuk kelas, ataukah keterlambatan mengumpulkan tugas. Yang paling penting ialah kejujuran peserta didik untuk menyampaikan alasan-alasan yang melatarbelakanginya. Kejujuran inilah yang patut diutamakan pendidik sebagai nilai toleransi atas keterbatasan peserta didik dalam proses pembelajaran. Sambil itu berkoordinasilah bersama orang tua agar mengenal lebih jauh kaperibadian peserta didikn, khususnya untuk peserta didik dengan nilai akademik "merah". Bersama-sama dengan orang tua mencari solusi untuk perbaikan 
kualitas diri peserta didik hingga kelak Ia menjadi pribadi yang berhasil dan berdaya guna untuk diri sendiri, keluarga, masyarakat, dan bangsa.

Ada satu hal penting dalam aspek kompetensi sosial yang masih menjadi polemik ialah keterbukaan pendidik atas kritik atau masukan orang lain. Sebagai pribadi dengan dasar nilai sosial yang tinggi, hal ini sangat diperlukan. Kritik ini tidak boleh dipandang sebagai suatu kebencian atau aib, namun yang paling penting adalah sarana untuk memperbaiki diri dalam melakukan pelayanan pendidikan. Jangan menyikapi kritik secara spontanitas dan emosional, namun lihatlah kritik itu sebagai medan pembuktian dan pengembangan diri. Sebab orang yang melakukan kritik sesungguhnya adalah orang-orang yang peduli dengan kemajuan kita, namun Ia lakukan dengan cara yang "unik dan berbeda". Kritik via supervisi akademik membantu pendidik dalam menyusun administrasi penilaian dan sebagai sebagai upaya pengendalia dan penjaminan mutu pembelajaran (Astuti, 2016; Ngaba, Anggit, Lalupanda, \& Sari, 2017. Poinnya, selama itu untuk kebaikan kita dan kebaikan bersama, kenapa kita tidak terbuka dan menerima kritikan, sederhana bukan?

\section{SIMPULAN}

Kompetensi sebagai bagian penting dalam pengembangan proses pembelajaran yang berkualitas yang wajib dimiliki oleh pendidik. Kian kompleksnya tantangan serta pertumbuhan penyelenggara pendidikan yang pesat membuat nilai tawar sebuah pendidikan menjadi lebih selektif. Proses selektif inilah yang semakin hari semakin ketat dan kompetitif, masyarakat mulai menyadari akan tuntutan kualitas sehingga anak-anak yang mereka "investasikan" harus mendapatkan pelayanan pendidikan yang memadai dan berkualitas sehinga berdaya guna dikemudian hari. Pertimbangan ini secara langsung mereferensi pada kompetensi para pendidik.

Meski telah terbukti partisipan memberi tanggapan terhadap kompetensi mengajar pendidik yang sangat tinggi $(69.0 \%)$. Namun sepantasnya pendidik tidak boleh berjumawa dalam penilaian temporal ini, namun teruslah memperbaiki diri agar layak memberi pelayanan pendidikan bagi peserta didik. Aktivitas belajar yang dilakukan masih berlaku untuk jangka yang panjang, sehingga dinamislah atas keterbukaan regulasi yang kerap digulirkan pemerintah, misalkan tercantum dalam syarat kualifikasi akademik dan pengurusan pangkat akademik. Semuanya tidak bisa lepas dari apa yang kita sebut sebagai kompetensi. Melakukan pemberdayaan terhadap aktivitas belajar peserta didik pun harus ditingkatkan dengan membuka jejaring kerjasama lintas sektor maupun instusi sebagai pengguna jasa lulusan. Upaya pengembagan diri perlu dilakukan secara berkala agar kompetensi pendidik selalu terstandarisasi dengan tuntutan zaman.

\section{UCAPAN TERIMA KASIH}

Ucapan terima kasih disampaikan kepada Ibu June A. Jacob, S.Pd., M.A., selaku Dekan Fakultas Keguruan dan Ilmu Pendidikan yang telah memberi dukungan anggaran melalui skim hibah penelitian unggulan Fakultas, Bapak Wilson L. Tisera, M.Si., Ph.D., selaku Kepala Lembaga Penelitian atas setiap masukan dalam kegiatan penelitian, dan Bapak Agustinus J. Nafie, S.Pd., M.Or., selaku Kaprodi Pendidikan Jasmani, Kesehatan, dan Rekreasi yang telah memberi izin atas penyelesaian hibah penelitian unggulan Fakultas tahun anggaran 2017. 


\section{DAFTAR PUSTAKA}

Ahmad, A., dan Jinggan, N. 2015. Pengaruh kompetensi kemahiran guru dalam pengajaran terhadap pencapaian akademik pelajar dalam mata pelajaran Sejarah. Jurnal Kurikulum \& Pengajaran Asia Pasifik. Vol. 3, No. 2: 1-11.

Asmarani, N. 2014. Peningkatan kompetensi profesional guru di sekolah dasar. Bahana Manajemen Pendidikan. Vol. 2, No. 1: 503-510.

Astuti, S. 2016. Penerapan supervisi akademik untuk meningkatkan kompetensi guru dalam menyusun administrasi penilaian di sd laboratorium uksw. Scholaria: Jurnal Pendidikan dan Kebudayaan Vol. 6, No. 1: 117-126.

Barinto. 2012. Hubungan kompetensi guru dan supervisi akademik dengan kinerja guru smp negeri sekecamatan Percut Sei Tuan. Jurnal Tabularasa PPs Unimed. Vol. 9, No. 2: 201-214.

Bhargava, A., and Pathy, M. 2011. Perception of student teacher about teaching competencies. American International Journal of Contemporary Research.Vol. 1, No. 1: 77-81.

Blegur, J., Wasak, M. R. P., Tlonaen, Z. A., and Manggoa, M. A. 2017. Students' behaviour of indiscipline syndrome in teaching and learning process. Educational Administration Review. Vol. 1, No. 1: 37-41.

Brundrett, M., and Silcock, P. 2002. Achieving competence, succes and excellence in teaching $\left(1^{\text {st }} \mathrm{ed}\right)$. London: Routledge Falmer.

Hakim, A. 2015. Contribution of competence teacher (pedagogical, personal, professional competence and social) on the performance of learning. The International Journal of Engineering and Science.Vol. 4, No. 2: 1-12.

Hamilton-Ekeke, J. T. 2013. Conceptual framework of teachers' competence in relation to students' academic achievement. International Journal of Networks and Systems. Vol. 2, No. 3: 15-20.

Indrawati, Y. 2006. Faktor-faktor yang mempengaruhi kinerja guru matematika dalam pelaksanaan kurikulum berbasis kompetensi (kbk) pada sekolah menengah atas Kota Palembang. Jurnal Manajemen dan Bisnis Sriwijaya. Vol. 4, No. 7: 41-58.

Ismail, H. N., Al-Zoubi, S. M., Rahman, M. B. A., and Al-Shabatat, A. M. 2009. Competence based teacher education (cbte): A training module for improving knowledge competencies for resource room teacher in Jordan. European Journal of Social Science. Vol. 10, No. 2: 166-178.

Ismail, M. I. 2010. Kinerja dan kompetensi guru dalam pembelajaran. Jurnal Lantera Pendidikan. Vol. 13, No. 1: 44-63.

Kementerian Pendidikan dan Kebudayaan. 2015. Buku pedoman sertifikasi pendidik untuk dosen (serdos) terintegrasi. Jakarta: Direktorat Jenderal Pendidikan Tinggi, Kementerian Pendidikan dan Kebudayaan, Republik Indonesia.

Kurniawan, A., Faisal., Murniati, N. A. Nyoman., dan Khoiri, N. 2011. Model pengembangan kompetensi profesional guru fisika kota Semarang pasca sertifikasi melalui mgmp. J2PF. Vol. 2, No. 2: 102114. 
Kurniawan, M. 2016. Developing teacher professionalism: a study on senior to junior supervision. Satya Widya. Vol. 32. No. 1: 29-40.

Manu, L., dan Blegur, J. 2017. Manajemen berbasis sekolah (cet. 1). Kupang: Jusuf Aryani Learning.

Manu, L., dan Manu, T. S. N. 2017. Profesi pendidikan dalam regulasi sistem pendidikan nasional di Indonesia (cet. 1). Kupang: Jusuf Aryani Learning.

Musfah, J. 2011. Peningkatan kompetensi guru melalui pelatihan dan sumber belajar: Teori dan praktik (cet. 1). Jakarta: Kencana Prenada Media Group.

Nadeem, M., Rana, M. S., Lone, A. H., Maqbool, S., Naz, K., and Ali, A. 2011. Teacher's competencies and factors affecting the performance of female teachers in Bahawalpur (Southern Punjab) Pakistan. International Journal of Business and Social Science. Vol. 2, No. 19: 217-222.

Ngaba, A. L., Anggit, G. P., Lalupanda, E. M., dan Sari, S. I. 2017. Pendendalian dan penjaminan mutu pengajaran melalui supervisi klinis. Satya Widya. Vol. 33, No. 1: 1-10.

Palupi, R. E. A., dan Sulton. 2017. Selangkah lebih dekat bersama formative assessment. Jurnal Dimensi Pendidikan dan
Pembelajaran. Vol. 5, No. 1: 140143.

Rubio, C. M. (2009). Effective teacherprofessional and personal skills. Revista de la Facultad de Education de Albacete. Vol.24: 35-46.

Saragih, M. D. 2013. Hubungan antara kompetensi dengan kinerja mengajar guru sd kecamatan Medang Deras kabupaten Batu Bara. Jurnal Tabularasa PPs Unimed.Vol. 10, No. 1: 1-12.

Suyantodan Djihad, A. 2012. Bagaimana menjadi calon guru dan guru professional (cet. 1). Yogyakarta: Multi Pressindo.

Syahruddin, Ernawati, A., Ede, M. N., Rahman, M. A. B., Sihes, A. J. B., and Daud, K. 2013. Teachers' pedagogical competence in schoolbased management: A case study in a public secondary school at ParePare, Indonesia. Journal of Educational and Learning. Vol. 7, No. 4: 213-218.

Ummah, K., Aunillah, dan Kurniawan, L. 2013. Analisis kompetensi guru matematika berdasarkan persepsi siswa. Jurnal Pendidikan Matematika.Vol. 1, No. 1: 51-60.

Wahyudi. 2010. Standar kompetensi profesional guru. Jurnal Pendidikan Sosiologi dan Humaniora. Vol. 1, No. 2: 107-119. 